\title{
Factors associated with the isolation of Candida Spp. from the oral microbiota of people living with HIV
}

\author{
Antônio Uelton Araújo da Silva ${ }^{1}$, Gabriela Cruz da Silva ${ }^{1}$, Érika Helena Salles de Brito ${ }^{1}$, Thiago Moura de Araújo ${ }^{1}$, \\ Maria Aparecida Alves de Oliveira Serra ${ }^{2}$, Ana Cristina Pereira de Jesus Costa ${ }^{2}$, Marcos Renato de Oliveira ${ }^{3}$, Roberto \\ Wagner Júnior Freire de Freitas ${ }^{4}$, Márcio Flávio Moura de Araújo*4 \\ ${ }^{1}$ University for International Integration of the Afro-Brazilian Lusophony, Redenção, Brazil \\ ${ }^{2}$ Federal University of Maranhão, Belo Horizonte, Brazil \\ ${ }^{3}$ Houston Methodist Research Institute, Houston, United States \\ ${ }^{4}$ Oswaldo Cruz Foundation, Eusébio, Brazil
}

Received: May 18, 2020

DOI: $10.5430 /$ cns.v8n3p22
Accepted: August 25, 2020

URL: https://doi.org/10.5430/cns.v8n3p22

\begin{abstract}
This study aimed to analyze the association between the isolation of Candida species in the oral cavity and the clinical and virulence factors of people living with Human immunodeficiency virus (HIV). This cross-sectional study, comprising 106 people living with HIV who were evaluated in an HIV-AIDS outpatient clinic in Fortaleza, Northeast of Brazil, data collection were conducted during August and November 2018. A saliva sample was also collected to isolate Candida. The virulence factors of extracellular and hemolytic phospholipase activities in isolated Candida strains were analyzed. The prevalence of oral Candida was $40.6 \%$, and the presence of oral Candida was associated with smoking habits $(p=.005)$, daily smoking $(p=.026)$, low weight $(p=.030)$, history of hospitalization $(p=.014), \mathrm{TCD}_{4}$ lymphocyte count $<200$ cells $/ \mathrm{mm}^{3}(p=.018)$, and detectable viral load $(p=.005)$. The multivariate analysis revealed that the variables smoking habits $(p=.008)$, viral load $(p=.011)$, and body mass index $(p=.011)$ were associated with the presence of oral Candida. Strong hemolytic and phospholipase activities were, respectively, identified in $74.4 \%$ and $72 \%$ of the isolated strains, mainly Candida albicans. As a main conclusion, the isolation of Candida from the oral cavity in people living with HIV/AIDS, has a strong association with the use of tobacco, even under an appropriate treatment.
\end{abstract}

Key Words: Candida, Human immunodeficiency virus, Cigarette smoke

\section{INTRODUCTION}

According to some studies the prevalence of Candida in the oral cavity of healthy people varies between $20 \%$ and $70 \%$. However, in children, elderly people, and people with immune system deficits, this prevalence is significantly higher than healthy people. In people living with Human immunodeficiency virus (PLHIV), oral candidiasis is considered an opportunistic infection and is one of the first signs of acquired immune deficiency syndrome (AIDS), which can be observed in $50 \%$ of HIV patients. Incidentally, $90 \%$ of PLHIV presented at least one oropharyngeal Candida infection during their lifetime. ${ }^{[1,2]}$

Candida infection is considered an immunosuppressive marker that decreases the TCD4 lymphocyte count, resulting

*Correspondence: Márcio Flávio Moura de Araújo; Email: oicam29@gmail.com; Address: Oswaldo Cruz Foundation, Rua São José, S/N, ZIP CODE: 61760-000, Eusébio, Brazil. 
in dysfunction, for up to 2 years' post infection. ${ }^{[3]}$ On the other hand, some authors observed that Candida infection in PLHIV reduced the replication of HIV in the macrophages, suggesting that inconsistent results were observed among researchers regarding Candida infection. ${ }^{[4,5]}$

In the general population, the main pathogenicity factors for Candida infection are as follows: smoking habits, extreme age, dental prostheses, xerostomia, dietary and immunological changes, infections, and oral neoplasia. ${ }^{[4,6]}$ In PLHIV, some factors related to oral candidiasis can also be considered as follows: TCD4 lymphocyte count $<200$ cells $/ \mathrm{mm}^{3}$; increased viral load; the use of several devices such as broadspectrum antibiotics, bladder probe, long-term nasoenteral probe, central venous catheter, mechanical ventilation, and corticoids; alcohol consumption; tobacco smoking; high carbohydrate consumption; and poor oral hygiene. ${ }^{[1,4]}$ Despite the positive effects of sleeping on the individual's neurological, hematological, and immunological system, studies analyzing the association between sleeping or any components related to it (duration, quality, efficiency) and the isolation of oral Candida and/or candidiasis have not been conducted yet. ${ }^{[7]}$

It is described that diseases caused by fungi kill more than 1.5 million and affect more than one billion people worldwide annually. ${ }^{[8]}$ In the past years, the relevance of medical mycology to human health has been significantly recognized in public health, specifically in countries located in the southern region of the world. This includes the development of diverse multidisciplinary studies (epidemiological, clinical, and preventive studies) that correlate with other diseases and conditions related to mycology. ${ }^{[9]}$ Additionally, in-depth knowledge regarding the Candida colonization process in PLHIV is significantly important for the early recognition and diagnosis of advanced, considering the fact that oral candidiasis is identified as a predictor factor of AIDS. ${ }^{[10,11]}$

Therefore, this exploratory study aimed to analyze the association between the isolation of Candida in the oral cavity and the sociodemographic and clinical factors (smoking habits, alcohol consumption, nutritional status, sleep quality, and sedentary lifestyle) of PLHIV and to analyze the virulence factors of extracellular phospholipase $(\mathrm{Pz})$ and hemolytic activities in the isolated Candida strains.

\section{Methods}

\subsection{Design}

This was a cross-sectional study conducted in PLHIV who were followed up in an HIV-AIDS outpatient clinic in Fortaleza city, Northeast of Brazil, in 2018.

Published by Sciedu Press

\subsection{Ethical considerations}

This study was approved by the Institutional Review Board from the Federal University for International Integration of the Afro-Brazilian Lusophony (UNILAB) (approval number: $2,691,682$ ). After presentation of the study and review of all the criteria the participants signed a copy of the informed consent form.

\subsection{Participants}

Participants with the following eligibility criteria were included in the study: participants diagnosed with HIV undergoing an outpatient treatment, both sexes, participants aged $\geq 18$ years, participants who were mentally capable of responding to an interview, and participants on antiretroviral therapy (ART) for at least 6 months. And the following characteristics were adopted as exclusion criteria: participants with a neurocognitive disorder associated with HIV (score $\leq$ 11 on the International HIV Dementia Scale), ${ }^{[11]}$ participants without medical/laboratory records of their TCD4 lymphocyte count for more than 1 year, and participants with a report or record of illicit drug use in the previous 30 days.

\subsection{Variables}

The outcome variable was the positive isolation of Candida in the oral cavity (yes or no) in PLHIV and the virulence factors (absent and strong).

The predictor variables of this study were as follows: sex, gender identity, sexual orientation, active sexual life, age (years), socioeconomic class, skin color, employment status, marital status, serodiscordant partner, family composition, and economic class. Furthermore, the clinical variable predictors were as follows: sleep quality, smoking habits, level of smoking, alcohol consumption, waist circumference (WC), neck circumference (NC), and nutritional status.

The predictor variables associated with HIV-AIDS treatment were as follows: the use of ART; time of ART use (years), time of diagnosis of HIV infection (years), current TCD4 lymphocyte count (cells $\left./ \mathrm{mm}^{3}\right)$, and current viral load $(<200$ copies/ml [undetectable] and $\geq 200$ copies/ml [detectable]).

\subsection{Measurement of clinical predictor variables}

To measure the clinical predictor variables, instruments widely known in the health literature were adopted. As an example, sleep quality was assessed using the Pittsburgh Sleep Quality Index (Brazilian Portuguese version). ${ }^{[12]}$ In this study, for statistical purposes, participants with scores $>$ 4 were classified as poor sleepers.

Related to the categorization of nutritional status, the BMI classification was as follows: low weight, eutrophic, overweight, grade I obesity, grade II obesity, and grade III obe- 
sity. ${ }^{[12]}$ The following NCs were considered normal: $\leq 37$ $\mathrm{cm}$ for men and $\leq 34 \mathrm{~cm}$ for women. ${ }^{[14]} \mathrm{WCs} \geq 102 \mathrm{~cm}$ for men and $\geq 88 \mathrm{~cm}$ for women were considered high. ${ }^{[15]}$

In relation to smoking, patients were classified as daily smokers, non daily smoking, quit smoking for at least a month and never smoked or had been smoking for less than a month. Regarding to alcoholism, the participants were classified as no alcohol consumition, alcohol consumition $\leq 1$ time a month, alcohol consumition 2-4 times a month, alcohol consumition 2-3 times a week and alcohol consumition $\geq 4$ times a week.

\subsection{Data collection}

Eligible PLHIV participants were interviewed by registered nurses at the hospital's outpatient clinic, in order to assess healthcare needs.

\subsection{Clinical sample collection}

A certified registered was responsible to conducted an clinical interview, physical examination, collection and transport of biological samples from the participants.

At the end of each interview, the registered nurse collected a sample from the patients' oral cavity microbiota using a sterile swab containing Stuart culture medium (Copan Transystem, Copan Innovating Together TM $($ ). The sample was collected from the oral cavity by fractioning the swab on the base of the tongue and on the valve papillae, an area with higher yeast concentration, in repetitive back and forth movements for at least 30 seconds. ${ }^{[16]}$ The entire process; from the clininc assesment to the swab collection demaind 48 hours to be completed. This process occurred in accordance to the recommendations by the manufacturer (Copan Transystem, Copan Innovating Together TM () ).

In the laboratory, the samples were stored in Petri dishes containing Sabouraud agar since this medium is indicated for yeast growth. After initial sample preparation, the Petri dishes were monitored daily for development and growth by microscopic analysis of Candida spp. colonies. In this process, the formation of white glabrous colonies with creamy aspect and texture and a smooth surface was observed during morphological observation. ${ }^{[17]}$

After growth, Candida species were identified using the CHROMagar Candida Medium microbiological method. With the inclusion of chromogenic substrates, the colonies presented with certain characteristics, that is, Candida albicans, Candida tropicalis, and Candida krusei colonies presented a different coloration. ${ }^{[18]}$

The dishes presenting no Candida spp. growth were discarded after 15 days, following the recommendations for biological waste disposal. ${ }^{[16]}$
The Prince (1982) methodology was used to determine extracellular $\mathrm{Pz}$ activity due to its practicality and reliability in several studies including large-scale research of different Candida isolates. Pz activity was determined by assessing the association between the diameter of the fungal colony and the total diameter including the colony and the precipitation zone. A pachymeter was used to measure the colonies and halos of precipitation. Thus, when $\mathrm{Pz}=1$, the isolate was $\mathrm{Pz}$ negative (absent activity); when $1>\mathrm{Pz} \geq 0.64$, the isolate was positive for $\mathrm{Pz}$ activity; and when $\mathrm{Pz}<0.64$, the isolate was strongly positive for Pz activity. ${ }^{[19]}$

The above-mentioned isolates were also tested for hemolytic activity using the methodology proposed by Favero (2011) and Luo (2001), in which they recommend the preparation of a culture medium with sheep blood, Sabouraud agar, and glucose for hemolytic evaluation. ${ }^{[20,21]}$ Hemolytic activity was determined by assessing the difference between the diameters described above. The data were interpreted as absent hemolytic activity for strains without a visible halo, weak hemolytic activity when halo $\leq 1 \mathrm{~mm}$, moderate hemolytic activity when halo ranged from 1.1 to $1.49 \mathrm{~mm}$, and strong hemolytic activity when halo $\geq 1.5 \mathrm{~mm} .^{[20,21]}$

The sample processing, inside of the microbiology laboratory, was performed by a registered nurse other than the one who assesed and conducted the patient interviews. Also, both nurses underwent a 16-hour training to become familiar with the aforementioned techniques and instruments. This training was conducted by the study coordinators.

\subsection{Statistical analysis}

Data were tabulated in an Excel spreadsheet and analyzed using the Statistical Package for the Social Sciences software version 23. The association between categorical qualitative variables were verified using the chi squared test. We have observed the assumption that all expected frequencies are greater than or equal to 1 . Otherwise, we conducted Fisher's exact tests. Multiple analysis by logistic regression was used for the variables that presented significance in the crude association analysis to identify the possible interactions between variables and eliminate the confounding factors. In this case, we assumed as the outcome variable the presence of candida in the oral cavity (yes or no), while the predictive variables were viral load (detectable or undetectable), smoking (yes or no) and BMI (underweight, normal or overweight/obesity). The magnitude of the association was expressed by point estimates and adjusted odds ratio intervals. The results were presented in graphs and tables. A significance level of 5\% was used for all inferential procedures. 


\section{Results}

\subsection{Sociodemographic characteristics of the partici- pants}

The sample comprised 106 people undergoing an outpatient treatment for HIV. Moreover, participants were predominantly men $(64.2 \%)$, were single $(40.6 \%)$, had varied racial ancestries $(51.9 \%)$, informal work (40.6\%), and belonged to the low-income economic class $(69.8 \%)$ (monthly income between 270.7 US dollars [USD] and 1,168 USD, with a mean of $412.0 \mathrm{pm} 325.9 \mathrm{USD}$ ).

Regarding to sexual preferences, the heterosexual orientation (50.9) and male gender identity (66\%) were predominant. A substantial portion of the sample had an active sexual life $(74.5 \%)$ and a single partner $(82.5 \%)$, serodiscordant $(47 \%)$ in some cases. Men $(p=.043)$ and heterosexuals $(p=.010)$ reported the highest number of sexual partners.

\subsection{Human immunodeficiency virus (HIV) treatment of the participants}

All participants were on ART, mostly using NRTIs (100\%). Only $27 \%$ of the participants used drugs other than ART on a daily basis. In this case, we investigated the predominance of antidepressants (23\%) and anxiolytics (15.3\%). Only $15.2 \%$ of the interviewees reported hospital admission after the diagnosis of infection. The most cited cause of hospitalization was tuberculosis (18.7\%). Most of the participants presented TCD4+ (92.2\%), TCD8+ (65\%), and undetectable viral load at the time of collection for this survey $(81.9 \%)$.

\subsection{Clinical characteristics and oral Candida in people living with HIV}

More than half of the sample $(64.5 \%)$ had a sedentary lifestyle, and a substantial portion of the sample never smoked $(68.2 \%)$ and did not consume alcohol (57.9\%). Despite this, they were healthy in terms of nutritional status (69.2\% were eutrophic) and anthropometric measurements (normal WC in $68.2 \%$ and normal NC in $74.2 \%$ of the participants).

Among the people who stated to smoke, the frequency of tobacco use were, as known smokers daily (17.8\%), does not smoke daily [light smokers] (9.3\%), and ex-smokers/quit smoking less than 30 days or never smoked $(3.7 \%)$. Variables sex $(p=.069)$ and alcohol consumption $(p=.107)$ did not influence the frequency of smoking. We have observed opposite in relation to physical exercise variable. In this case, people who smoke daily (89.4\%) and light smokers (50\%) were sedentary $(p=.025)$.

Regarding sleep duration, most participants sleep $>7$ hours (41.5\%) and 6-7 hours (31.1\%) daily. The best parameter for sleep efficiency ( $>85 \%$ ) was the most chosen option during Published by Sciedu Press the interviews (83\%). Almost half of the studied sample had no bed partner (50.5\%). Thus, $67 \%$ of the sample comprised people with poor sleep quality.

Of the patients investigated, a total of $40.6 \%$ presented Candida spp. in the oral cavity. The following strains were identified: C. albicans $(74.4 \%)$, C. tropicalis $(9.3 \%)$, Candida glabrata (2.3\%), Candida parapsilosis (2.3\%), and Candida $s p$. $(11.6 \%)$. Related to the isolated strains, $72 \%$ released extracellular Pz; in $46.5 \%$ of these cases, the activity was considered strong. Moreover, among the Candida strains, C. albicans had the strongest $\mathrm{Pz}$ activity (59.3\%). On the contrary, C. tropicalis (75\%) and C. glabrata (100\%) showed negative $\mathrm{Pz}$ activity. There was a strong hemolytic activity in $74.4 \%$ of the isolated strains. C. albicans, $C$. tropicalis, and C. glabrata presented this activity in $75 \%, 100 \%$, and $100 \%$ of the samples, respectively.

No differences were observed among the study participants regarding the sociodemographic characteristics analyzed and the isolation of oral Candida.

Of the PLHIV studied, most were smokers (60.6\%), but tobacco smoking was not performed daily (70\%). Moreover, $80 \%$ of the patients with positive samples for the fungus were underweight $(p=.030)$ (see Table 1).

Positive oral Candida was predominant in PLHIV with a history of hospitalization (68.8\%), TCD4 lymphocyte count $<200$ cells $/ \mathrm{mm}^{3}$ (85.7\%), and detectable viral load (68.4) $(p<.05)$. There was no statistically significant association between sleep quality and Candida isolation in PLHIV $(p>$ .05) (see Table 2).

The variable sleep quality also had no influence on the hemolytic $(p=.201)$ and $\mathrm{Pz}(p=.629)$ strength of the isolated strains.

In the regression model, the factors that were positively associated with oral Candida isolation in PLHIV were as follows: detectable viral load, being a smoker, and being eutrophic. Smokers and PLHIV with detectable viral load presented a respective chance of having Candida 3.5 and 4.8 times higher than the other participants (see Table 3).

\section{Discussion}

Candida is common throughout the digestive tract and is associated with neonatal infections, cavities, endocarditis, and presence of biofilm. This study identified the presence of Candida in $40.6 \%$ of the participants investigated. This prevalence was similar to the values observed in people undergoing autologous bone marrow transplantation (40.7\%) and asymptomatic PLHIV (51.3\% and 52.5\%), but lower than the values found in hospitalized HIV patients (50.4\%, $53.5 \%, 73.3 \%, 73.4 \%, 80 \%$, and $83 \%) .{ }^{[6,22-28]}$ 
Table 1. Presence of Candida by lifestyle habits and nutritional status. Fortaleza, Brazil, 2019

\begin{tabular}{|c|c|c|c|c|c|}
\hline \multirow{2}{*}{ Variables } & \multicolumn{2}{|c|}{ With Candida } & \multicolumn{2}{|c|}{ Without Candida } & \multirow{2}{*}{$p$-value } \\
\hline & $\mathbf{N}$ & $\%$ & n & $\%$ & \\
\hline Physical exercise & & & & & $.404^{*}$ \\
\hline Yes & 13 & 35.1 & 24 & 64.9 & \\
\hline No & 30 & 43.5 & 39 & 56.5 & \\
\hline Active sexual life & & & & & $.167^{*}$ \\
\hline Yes & 29 & 36.7 & 50 & 63.3 & \\
\hline No & 14 & 51.9 & 13 & 48.1 & \\
\hline Smoking & & & & & $.005^{*}$ \\
\hline Yes & 20 & 60.6 & 13 & 39.4 & \\
\hline No & 23 & 31.5 & 50 & 68.5 & \\
\hline Level of smoking & & & & & $.026^{* *}$ \\
\hline Smokes daily & 11 & 57.9 & 8 & 42.1 & \\
\hline Does not smoke daily & 7 & 70.0 & 3 & 30.0 & \\
\hline Quit smoking at least a month before & 2 & 50.0 & 2 & 50.0 & \\
\hline Never smoked or quit at least a month before & 23 & 31.5 & 50 & 68.5 & \\
\hline Alcohol consumption & & & & & $.482^{* *}$ \\
\hline Never & 27 & 42.9 & 36 & 57.1 & \\
\hline$\leq 1$ time a month & 6 & 27.3 & 16 & 72.7 & \\
\hline 2-4 times a month & 7 & 43.8 & 9 & 56.3 & \\
\hline $2-3$ times a week & 2 & 66.7 & 1 & 33.3 & \\
\hline$\geq 4$ times a week & 0 & 0.0 & 1 & 100.0 & \\
\hline Neck circumference & & & & & $.314^{*}$ \\
\hline Normal & 35 & 43.8 & 45 & 56.3 & \\
\hline High & 7 & 31.8 & 15 & 68.2 & \\
\hline Waist circumference & & & & & $.128^{*}$ \\
\hline Normal & 33 & 45.2 & 40 & 54.8 & \\
\hline High & 8 & 28.6 & 20 & 71.4 & \\
\hline BMI & & & & & $.030^{* *}$ \\
\hline Low weight & 4 & 80.0 & 1 & 20.0 & \\
\hline Normal & 33 & 44.6 & 41 & 55.4 & \\
\hline Overweight/obesity & 6 & 23.1 & 20 & 76.9 & \\
\hline
\end{tabular}

Note. ${ }^{*}$ Chi-squared test; ${ }^{* *}$ Fisher's exact test

It is important to consider the period and location of these studies (Brazil, China, Nigeria, Turkey) once the incidence of fungal infections has increased in developing countries due to the use of ART and new diagnostic methods. ${ }^{[29]}$ Moreover, the participants in this study come from the outpatient clinics and not from the hospitals; hence, these participants may present basic pathologies that aggravate their clinical status.

However, an in-depth discussion is required as this infection may become symptomatic as viral load fluctuates and defense cells decrease. Some authors do not recommend routine fungal infection screening and investigation because this is relatively expensive. Nevertheless, more specific actions need to be developed considering that opportunistic infections, including fungal infections, are responsible for PLHIV diseases, hospitalizations, and deaths. ${ }^{[6]}$ Other authors reported that Candida colonization in the oral cavity can be used to evaluate the effectiveness of antiretrovirals, ${ }^{[29]}$ reinforcing the need for more studies on mucosal colonization by Candida spp. in people living with HIV/AIDS.

There was no association between the isolation of Candida in the oral cavity and the sociodemographic factors discussed in this study. However, according to meta-analysis data, it is important to emphasize that the negative sociodemographic 
predictors for the quality of life and well-being of PLHIV are ence of a supportive social network are considered positive as follows: poverty, age $\geq 35$ years, alcohol consumption, predictors of PLHIV's quality of life. ${ }^{[31]}$ and drug abuse. On the contrary, condom use and the pres-

Table 2. Presence of Candida by clinical characteristics. Fortaleza, Brazil, 2019

\begin{tabular}{|c|c|c|c|c|c|}
\hline \multirow{2}{*}{ Variables } & \multicolumn{2}{|c|}{ With Candida } & \multicolumn{2}{|c|}{ Without Candida } & \multirow{2}{*}{$p$-value } \\
\hline & n & $\%$ & $\mathbf{N}$ & $\%$ & \\
\hline Use of drugs other than ART & & & & & $.680^{*}$ \\
\hline Yes & 10 & 37.0 & 17 & 63.0 & \\
\hline No & 32 & 41.6 & 45 & 58.4 & \\
\hline History of hospitalization & & & & & $.014^{*}$ \\
\hline Yes & 11 & 68.8 & 5 & 31.3 & \\
\hline No & 32 & 36.0 & 57 & 64.0 & \\
\hline TCD4 lymphocyte count & & & & & $.018^{* *}$ \\
\hline$\geq 200$ cells $/ \mathrm{mm}^{3}$ & 31 & 37.3 & 52 & 62.7 & \\
\hline$<200$ cells $/ \mathrm{mm}^{3}$ & 6 & 85.7 & 1 & 14.3 & \\
\hline TCD8 lymphocyte count & & & & & - \\
\hline$\geq 200$ cells $/ \mathrm{mm}^{3}$ & 26 & 40.0 & 39 & 60.0 & \\
\hline$<200$ cells $/ \mathrm{mm}^{3}$ & 0 & - & 0 & - & \\
\hline Viral load & & & & & $.005^{*}$ \\
\hline Undetectable & 29 & 33.7 & 57 & 66.3 & \\
\hline Detectable & 13 & 68.4 & 6 & 31.6 & \\
\hline Sleep Quality & & & & & $.811^{*}$ \\
\hline Poor sleeper & 34 & 40.0 & 51 & 60.0 & \\
\hline Good sleeper & 9 & 42.9 & 12 & 57.1 & \\
\hline
\end{tabular}

Note. ${ }^{*}$ Chi-squared test; ${ }^{* *}$ Fisher's exact test

Table 3. Logistic regression model for the presence of Candida. Fortaleza, Brazil, 2019

\begin{tabular}{lccc}
\hline Variables in the equation & Odds ratio & Confidence interval 95\% & $\boldsymbol{p}^{\text {-value }}$ \\
\hline Viral load & & & $\mathbf{0 1 1}$ \\
$\quad \begin{array}{l}\text { Detectable } \\
\text { Undetectable }\end{array}$ & 4.80 & $1.44-15.97$ & \\
$\begin{array}{l}\text { Smoking } \\
\text { Yes }\end{array}$ & 1 & - & $\mathbf{. 0 0 8}$ \\
No & 3.59 & $1.40-9.22$ & \\
BMI & 1 & - & $\mathbf{0 6 6}$ \\
Low weight & 10.92 & $0.85-140.18$ & $\mathbf{. 0 2 0}$ \\
Normal & 4.05 & $1.25-13.14$ & \\
$\quad$ Overweight/obesity & 1 & & \\
\hline
\end{tabular}

Note. ${ }^{*}$ Wald test 
Additionally, a recent meta-analysis shows that adherence to ART, CD4 lymphocyte count, and presence of comorbidities are the major clinical predictors of PLHIV's quality of life. ${ }^{[32]}$ In this study, for example, an association was identified after adjusting the following variables: viral load (detectable), smoking habits (presence), and nutritional status (normal).

It is important to mention that both detectable viral load and candidiasis are events directly associated with the maintenance of the human immune system. Therefore, the presence of Candida in the oral cavity as a marker of HIV progression should not be overlooked. ${ }^{[10]}$ Additionally, defects in specific TCD4 cell subsets may cause some of these infections, such as mycobacteriosis and candidiasis. ${ }^{[33]}$

Regarding smoking habits it is important to highlight the fact that products that cause combustion such as cigarettes favor the development of candidiasis considering that smoke irritates the mucous membranes and lacerations facilitate the penetration of fungus in the oral mucosa. In addition, smoking can reduce imune system function, and by this facilitating the process of oral colonization by Candida spp. C. albicans strains increase their virulence when exposed to cigarette smoke. ${ }^{[34,35]}$ Moreover, animal model experimentations have shown that long exposure to cigarettes attenuates the protection of the epithelium of the oral mucosa against $\mathrm{C}$. albicans as evidenced by inflammation. ${ }^{[36]}$

This study shows that the strains in general presented high hemolytic and $\mathrm{Pz}$ activities. Although all species present hemolytic activity, the quantity of cultivated strains ( $\mathrm{n}=$ 43) shows that the $C$. albicans $(\mathrm{n}=32)$ isolates have higher hemolytic activity compared to the other species. It is important to highlight that all strains of $C$. albicans presented hemolytic activity, of which $71 \%$ can be classified as moderate. The production of hemolytic activity by Candida species can be justified by the fact that hemolysin is considered a nanoprotein that is linked to the cellular appearance of this genus of yeasts, enabling the exploration of iron from the host. ${ }^{[37]}$ Correspondingly, iron is an essential cofactor for its proteins and contributes to several metabolic processes, such as cellular respiration and DNA synthesis. ${ }^{[38]}$

The production of the phospholipase enzyme is considered an important virulence factor of Candida spp., since it binds the yeast to the target tissue and generates an entry pathway in the same hydrolyzed phospholipids and degrading the host cell membranes, being fundamental for the establishment of the infectious process. ${ }^{[37]}$ According to the present research, all isolated Candida species produce phospholipases, with C. albicans having the strongest $\mathrm{Pz}$ activity, corroborating the findings of another study that described phospholipae production in $61.42 \%$ of $C$. albicans isolates, in addition the majority were considered as strong producers. ${ }^{[37]}$

Our findings regarding $\mathrm{Pz}^{[17,30,39,40]}$ and hemolytic activities ${ }^{[21,39]}$ in PLHIV are consistent with the findings of several previous studies.

This activity may have been underestimated because individuals using ART have yeasts with lower expression of some enzymes related to the virulence process. ${ }^{[30]}$ Therefore, the presence of hemolytic and $\mathrm{Pz}$ activities in the strains of this study, which are even associated with ART, demonstrates the high potential for virulence and the potential for infections of these strains.

Currently, effective ART has ensured immune reconstitution; hence, oropharyngeal and esophageal candidiasis are still considered clinically relevant. Both diseases are predominantly caused by $\mathrm{C}$. albicans, a commensurate microbe in healthy individuals but a likely aggressive pathogen in PLHIV. ${ }^{[41-43]}$

\section{Limitations of the study}

This study had some limitations in the evaluation of sleep quality and in Candida isolation. Sleep was evaluated using a psychometric scale that, although it was translated and transculturally adapted to Brazilian Portuguese, once this scale is less accurate for measurement of sleep disorders if compared to polysomnography and actigraphy.

In Candida isolation, neither control of variables of interest such as glycemia and/or glycated hemoglobin values nor the evaluation of saliva composition were evident considering that PLHIV experience salivary changes that may favor Candida colonization and adherence in the oral cavity. ${ }^{[26]}$ Finally, this study should be replicated in hospitalized people diagnosed with AIDS to analyze the effect of the predictors smoking habits, BMI, and viral load on the remission or progression of candidiasis cases in this group.

\section{Conclusions}

There is an association between the use of tobacco and isolation of Candida from the oral cavity in people living with HIV/AIDS, even with appropriate treatment.

\section{ACKNOWLEDGEMENTS}

We would like to express our gratitude to all the patients who participated in this research.

\section{CONFlicts OF InTEREST Disclosure}

The authors declare they have no conflicts of interest. 


\section{REFERENCES}

[1] Giolo MP, Svidzinski TIE. Fisiopatogenia, epidemiologia e diagnóstico laboratorial da candidemia. Jornal Brasileiro de Patologia e Medicina Laboratorial. 2010; 46(3): 225-234. https ://doi.org/ $10.1590 / \mathrm{S} 1676-24442010000300009$

[2] Mushi MF, Bader O, Taverne-Ghadwal L, et al. Oral candidiasis among African human immunodeficiency virus-infected individuals: 10 years of systematic review and meta-analysis from sub-Saharan Africa. Journal of Oral Microbiology. 2017; 9(1). PMid: 1317579. https://doi.org/10.1080/20002297.2017.1317579

[3] Stuehler C, Bernardini C, Elzi L, et al. (Immune recovery in HIVinfected patients after Candida esophagitis is impaired despite longterm antiretroviral therapy. AIDS. 2016; 30(12): 1923-1933. PMid: 27149086. https://doi.org/10.1097/QAD.00000000000011 26

[4] Cerqueira DF, Portela MB, Pomarico L, et al. Oral Candida colonization and its relation with predisposing factors in HIV-infected children and their uninfected siblings in Brazil: the era of highly active antiretroviral therapy. Journal of Oral Pathology Medicine. 2010; 39(2): 188-194. PMid: 20040023. https://doi.org/10.1 $111 / j .1600-0714.2009 .00857 . x$

[5] Rodriguez-Rodrigues C, Lenicov FR, Jancic C, et al. Candida albicans delays HIV-1 replication in macrophages. PloS ONE. 2013; 8(8): e72814. PMid: 24009706. https://doi.org/10.1371/jo urnal.pone. 0072814

[6] Goulart LS, Souza WWR, Vieira CA, et al. Colonização oral por espécies de Candida em pacientes HIV positivo: estudo de associação e suscetibilidade antifúngica. Einstein (São Paulo). 2018; 16(3). PMid: eAO4224.

[7] Tufik S. Medicina e biologia do sono (1th ed.). Barueri, SP: Manole; 2008.

[8] Bongomin F, Gago S, Oladele RO, et al. Global and multi-national prevalence of fungal diseases-estimate precision. Journal of Fungi (Basel). 2017; 3(4): 57. PMid: 29371573. https://doi.org/10 .3390/jof 3040057

[9] Cole DC, Govender NP, Chakrabati C, et al. Improvement of fungal disease identification and management: combined health systems and public health approaches. Lancet Infection Diseases. 2017; 17(12): 412-419. https://doi.org/10.1016/S1473-3099(17 ) 30308-0

[10] Spalanzani RN, Mattos K, Marques LI, et al. Clinical and laboratorial features of oral candidiasis in HIV-positive patients. Revista da Sociedade Brasileira de Medicina Tropical. 2018; 51(3): 352-356. PMid: 29972567. https ://doi .org/10.1590/0037-8682-024 $1-2017$

[11] Rodrigues RA, Oliveira RL, Grinsztejn B, et al. Validity of the International HIV Dementia Scale in Brazil. Arquivos de NeuroPsiquiatria. 2013; 71(6): 376-379. PMid: 23828527. https ://doi. org/10.1590/0004-282X20130042

[12] Bertolazi AN, Fagondes SC, Hoff LS, et al. Validation of the Brazilian Portuguese version of the Pittsburgh Sleep Quality Index. Sleep Medicine. 2011; 12(1): 70-75. PMid: 21145786. https: //doi.org/10.1016/j.sleep.2010.04.020

[13] World Health Organization (WHO). Obesity, preventing and managing the global epidemic. WHO Technical Report Series. 2000; 894: 1-253.

[14] Pereira DCR, Araújo MFM, Freitas RWJF, et al. Neck circumference as a potential marker of metabolic syndrome among college students-2014. Revista Latino-Americana de Enfermagem. 2014; 22(6): 973-979. PMid: 25591092. https://doi.org/10.1590/ 0104-1169.3565.2505

Published by Sciedu Press
[15] Brazilian Association for Obesity and Metabolic Syndrome Study (ABESO). Brazilian Guidelines for Obesity (4th ed.). São Paulo, SP: ABESO. 2016 [Assessed May 25, 2019]. Available from: http://www.abeso.org.br/uploads/downloads/92/ $57 \mathrm{fccc} 403 \mathrm{e} 5 \mathrm{da}$.pdf

[16] Brazilian Health Surveillance Agency. Microbiologia clínica para o controle de infecção relacionada à assistência à saúde: detecção e identificação de fungos de importância médica. Brasília, DF: ANVISA. 2010 [Assessed Jun 21, 2018]. Available from: https://www20.anvisa.gov.br/segurancadopaciente/in dex.php/publicacoes/item/deteccao-e-identificacao -de-fungos-de-importancia-medica

[17] Paul S, Kannan I. Molecular identification and antifungal susceptibility pattern of Candida species isolated from HIV infected Patients with candisiasis. Current Medical Mycology. 2019; 5(1): 21-26. https://doi.org/10.18502/cmm.5.1.533

[18] Jafari Z, Motamedi M, Jalalizand N, et al. Comparison of CHROMagar, polymerase chain reaction-restriction fragment length polymorphism, and polymerase chain reaction-fragment size for the identification of Candida species. Current Medical Mycology. 2017; 3(3): 1015. PMid: 29707668. https : //doi .org/10.29252/cmm.3.3.10

[19] Price MF, Wilkinson ID, Gentry LO. Plate method for detection of phospholipase activity in Candida albicans. Medical Mycology. 1982; 20(5): 7-14. PMid: 7038928. https://doi.org/10.1080/0036 2178285380031

[20] Favero D, Franca EJ, Furlaneto-Maia L, et al. Production of haemolytic factor by clinical isolates of Candida tropicalis. Mycoses. 2011; 54: e816-e820. PMid: 21672047. https://doi.org/10.1 $111 / j .1439-0507.2011 .02035 . x$

[21] Luo G, Samaranayake LP, Yau JY. Candida species exhibit differential in vitro hemolytic activities. Journal of Clinical Microbiology. 2001; 39: 2971-2974. PMid: 11474025. https://doi.org/10.1 128/JCM. 39.8.2971-2974. 2001

[22] Silva RF. Prevalência de Candida spp. na cavidade bucal de pacientes submetidos a transplante autólogo de célulastronco hematopoiéticas [dissertation]. São José dos Campos, SP, Brasil. 2016 [Assessed Jan 25, 2019]. Available from: https://repositorio.unesp.br/bitstream/handle/ 11449/148679/silva_rf_me_sjc.pdf?sequence=3

[23] Goulart LS, Souza W, Vieira CA, et al. Oral colonization by Candida species in HIV-positive patients: association and antifungal susceptibility study. Einstein (Sao Paulo, Brazil). 2018; 16(3). PMid: eAO4224. https://doi.org/10.1590/S1679-4508201 $8 \mathrm{A04224}$

[24] Paula S, Morey A, Santos J, et al. Oral Candida colonization in HIV-infected patients in Londrina-PR, Brazil: antifungal susceptibility and virulence factors. Journal of Infections Developemnt Countries. 2015; 9(12): 1350-1359. PMid: 26719941. https: //doi.org/10.3855/jidc. 6970

[25] Hartmann A, Missio R, Hammad M, et al. Incidência de Candida spp. na mucosa oral de pacientes infectados pelo vírus da imunodeficiência humana (HIV) no município de Santo Ângelo-RS. Revista de Epidemiologia e Controle de Infecções. 2016; 6(3): 125-130. https://doi.org/10.17058/reci.v6i3.6556

[26] Maheshwari M, Kaur R, Chadha S. Candida Species Prevalence Profile in HIV Seropositive Patients from a Major Tertiary Care Hospital in New Delhi, India. Journal of Pathogens. 2016. PMid: 6204804. https://doi.org/10.1155/2016/6204804

[27] Lin JN, Lin CC, Lai CH, et al. Predisposing factors for oropharyngeal colonization of yeasts in human immunodeficiency virus-infected patients: a prospective cross-sectional study. Journal of Microbiology, 
Immunollogy and Infection. 2013; 46(2): 129-135. PMid: 22921200 https://doi.org/10.1016/j.jmii.2012.07.009

[28] Terças AL, Marques SG, Moffa EB, et al. Antifungal drug susceptibility of Candida Species isolated from HIV-positive patients recruited at a public hospital in São Luís, Maranhão, Brazil. Frontiers in Microbiology. 2017; 8: 298. https://doi.org/10.3389/fmicb. 2017 .00298

[29] Limper AH, Adenis A, Le T, et al. Fungal infections in HIV/AIDS Lancet Infection Diseases. 2017; 17(11): e334-e343. https : //doi org/10.1016/S1473-3099 (17) 30303-1

[30] Menezes RP, Riceto EBM, Borges AS, et al. Evaluation of virulence factors of Candida albicans isolated from HIV-positive individuals using HAART. Archives Oral Biology. 2016; 66: 61-5. PMid: 26913969. https://doi.org/10.1016/j.archoralbio. 2016.02 .004

[31] Ghiasvand H, Waye KM, Noroozi M, et al. Clinical determinants associated with quality of life for people who live with HIV/AIDS: a Metaanalysis. BMC Health Services Research. 2019; 19(1): 768. PMid: 31665007. https://doi.org/10.1186/s12913-019-4659-z

[32] Ghiasvand H, Higgs P, Noroozi M, et al. Social and demographical determinants of quality of life in people who live with HIV/AIDS infection: evidence from a meta-analysis. Biodemography and Social Biology. 2020; 65(1): 57-72. PMid: 30882251. https : //doi .org/ $10.1080 / 19485565.2019 .1587287$

[33] Zhang Q, Frange P, Blanche S, et al. Pathogenesis of infections in $\mathrm{HIV}$-infected individuals: insights from primary immunodeficiencies. Current Opinion Immunology. 2017; 48: 122-133. PMid: 28992464. https://doi.org/10.1016/j.coi.2017.09.002

[34] Mokeem SA, Abduljabbar T, Al-Kheraif AA, et al. Oral Candida carriage among cigarette- and waterpipe-smokers, and electroniccigarette users. Oral Diseases. 2018; 25(1): 319-326. PMid: 29800492. https ://doi.org/10.1111/odi.12902

[35] Wu J, Li M, Huang R. The effect of smoking on caries-related microorganisms. Tobbaco Induced Diseases. 2019; 17: 32. PMid: 31516475. https://doi.org/10.18332/tid/105913
[36] Ye P, Wang X, Ge S, et al. Long-term cigarette smoking suppresses NLRP3 inflame some activation in oral mucosal epithelium and attenuates host defense against Candida albicans in a rat model. Biomedical Pharmacotherapy. 2019; 113. PMid: 30851547. https ://doi.org/10.1016/j.biopha.2019.01.058

[37] Mohammadi F, Ghasemi Z, Familsatarian B, et al. Relationship between antifungal susceptibility profile and virulence factors in Candida albicans isolated from nail specimens. Revista da Sociedade Brasileira de Medicina Tropical. 2020; 53. PMid: 32049200 https://doi .org/10.1590/0037-8682-0214-2019

[38] Ahmad Khan MS, Alshehrei F, Al-Ghamdi SB, et al. Virulence and biofilms as promising targets in developing antipathogenic drugs against candidiasis. Future Sci OA. 2020; 6(2). FSO440. PMid: 32025329. https://doi.org/10.2144/f soa-2019-0027

[39] Andreola P, Demathé A, Galafassi D, et al. Estudo comparativo entre a produção de fosfolipases extracelulares e proteinases do gênero Candida isoladas a partir de infecções de cavidade oral. Revista de Odontologia da UNESP. 2016; 45(4): 219-226. https: //doi.org/10.1590/1807-2577.26115

[40] Lahkar V, Saikia L, Patgiri SJ, et al. Estimation of biofilm, proteinase $\&$ phospholipase production of the Candida species isolated from the oropharyngeal samples in HIV-infected patients. The Indian journal of Medical Research. 2017; 145(5): 635-640.

[41] Wibawa T, Praseno, Aman AT. Virulence of Candida albicans isolated from HIV infected and non infected individuals. Springerplus. 2015; 4: 408. PMid: 26266079. https://doi.org/10.1186/s4 0064-015-1215-0

[42] Cassone A, Cauda R. Candida and candidiasis in HIV-infected patients: where commensalism, opportunistic behavior and frank pathogenicity lose their borders. AIDS. 2012; 26(12): 1457-72. PMid: 22472853. https://doi.org/10.1097/QAD.0b013e32 $83536 \mathrm{ba} 8$

[43] Kirti YK. Prevalence of oral candidiasis in Indian HIV sero-positive patients with CD4+ cell count correlation. Indian Journal of Otolaryngology and Head and Neck Surgery: Official Publication of the Association of Otolaryngologists of India. 2019; 71(1): 124-127. PMid: 30906728. https://doi .org/10.1007/s12070-018-1342-3 